\title{
Recurrent canalicular granulation tissue following syringing and probing
}

Kah Lay Oh, Arvinth Rajagopal, Juliana Jalaluddin

Department of Ophthalmology, Hospital Pakar Sultanah Fatimah, Muar, Johor, Malaysia

\section{Abstract}

A 70-year-old woman presented with lower lid swelling in the right eye for a duration of 5 months. There was no associated trauma or surgical intervention to the canaliculi. On examination, there was a soft and diffuse swelling adjacent to the lower punctum. Syringing and probing were done, revealing incomplete blockage of the lacrimal system. After a week of syringing, a growth arising from the lower punctum was noted. Excision was done and histopathological examination revealed granulation tissue with no malignancy seen. At 6 weeks post-excision, the granulation tissue recurred and was treated medically as the patient remained asymptomatic.

Keywords: canalicular, granulation tissue, probing, punctum, syringing

Correspondence: Dr. Kah Lay Oh, Department of Ophthalmology, Hospital Pakar Sultanah Fatimah, Muar, Johor, Malaysia.

E-mail:szeto_blue@yahoo.com 


\section{Kejadian semula tisu granulasi kanalikular selepas prosedur penyiasatan sistem lakrimal dan syringing}

\section{Abstrak}

Seorang wanita berusia 70 tahun mengalami pembengkakan pada sebelah bawah kelopak mata di sebelah kanan selama 5 bulan. Tiada sejarah trauma atau intervensi pembedahan ke atas kanalikular sebelum ini. Ketika pemeriksaan, terdapat pembengkakan lembut dan mendatar berdekatan dengan bahagian bawah punktum. Berdasarkan syringing dan pemeriksaan yang dilakukan, terdapat penyumbatan separa pada sistem lakrimal. Selepas satu minggu proses syringing, pembengkakan semula timbul dari punktum bawah. Eksisi dilakukan dan pemeriksaan histopatologi menunjukkan tisu granulasi tanpa wujudnya tanda pertumbuhan sel malignan. Selepas 6 minggu eksisi, tisu granulasi berulang lagi dan dirawat secara ubatan kerana pesakit tidak mengalami sebarang simptom.

Kata kunci: kanalikular, penyiasatan sistem lakrimal, punktum, syringing, tisu granulasi

\section{Introduction}

Granulation tissue formation of the eye is a common occurrence. As sequelae of any ocular procedure such as strabismus surgery or incision and curettage, the eye develops chronic inflammation. However, granulation tissue in the lower punctum is rare. Classic examples include punctal plug insertion in the treatment of dry eyes or dacryocystorhinostomy silicone tube insertion for nasolacrimal duct obstruction., ${ }^{1,2}$ We report a case of recurrent lower punctum granulation tissue after an episode of syringing and probing.

\section{Case report}

A 70-year-old Malay woman came to our eye clinic with the complaint of lower lid swelling in the right eye for 5 months. The swelling was confined to the nasal side of the lower lid and was associated with minimal epiphora and clear discharge. Prior to presentation, the swelling had ruptured spontaneously but subsequently recurred. She sought treatment at a primary care setting and was given topical antibiotics. However, the swelling remained the same. She denied any previous trauma, insect 
bite, or any surgical intervention to the puncti. Her medical history included hypertension on treatment and bilateral knee osteoarthritis.

Her visual acuity showed OD 6/24, improved to $6 / 12$ with pinhole, and OS 6/36, improved to $6 / 18$ with pinhole. Examination of the right anterior segment revealed a soft and diffuse swelling adjacent to the lower punctum. The surrounding canalicular area appeared minimally erythematous and oedematous. The lower punctum was not obliterated and its ampulla appeared slightly dilated. There was no evidence of meibomitis. The upper punctum was normal in appearance. She also had bilateral immature cataract and right epiretinal membrane. Other examinations were unremarkable.

As chronic canaliculitis with a suspicious canalicular obstruction was suspected, syringing and probing was performed. A 26-G Rycroft cannula attached to a syringe filled with balanced salt solution was used. Syringing of the upper punctum revealed a hard stop with regurgitation. However, there was a soft stop with no regurgitation from the lower punctum. A diagnosis of right incomplete blockage of the lacrimal excretory system was made. Topical dexamethasone and fusidic acid ointment were started, and the patient was advised to apply warm compresses at home.

During her review 1 week later, a soft and pink mass arising from the lower punctum was noted. The mass was excised for diagnostic purposes and histopathological examination revealed inflamed granulation tissue with no malignant cells (Fig. 1).

At 6 weeks post-excision, the granulation tissue of the lower punctum recurred. The oculoplastic team was consulted and the lesion was treated medically with topical dexamethasone, in view of the patient remaining asymptomatic (Fig. 2).

\section{Discussion}

Granulation tissue of the canaliculus is commonly associated with procedures involving the puncti, such as silicon plugs and stent insertion..$^{2-4}$ In this case, the patient developed it after syringing and probing, which is rare. This procedure is commonly done as an office procedure to find obstructions in the canaliculi. Pre-existing chronic inflammation from canaliculitis and syringing may worsen the inflammation and induce granuloma formation. A mixture of inflammatory cells and hyperplastic lymphoid tissues protrude from the lower punctum, leading to development of the tissue. Inadequate control of inflammation and persistent canaliculitis may lead to recurrence.

Surgical excision is the treatment of choice to remove such granulation tissue. The use of antimetabolites has been reported to reduce the rate of recurrence. Durmus et al. reported that mitomycin-C $0.4 \mathrm{mg} / \mathrm{ml}$ for 3 minutes over the base of the recurrent granuloma resulted in reduced recurrence. ${ }^{5}$ However, in our case the patient did not develop any symptoms such as epiphora or foreign body sensation. 


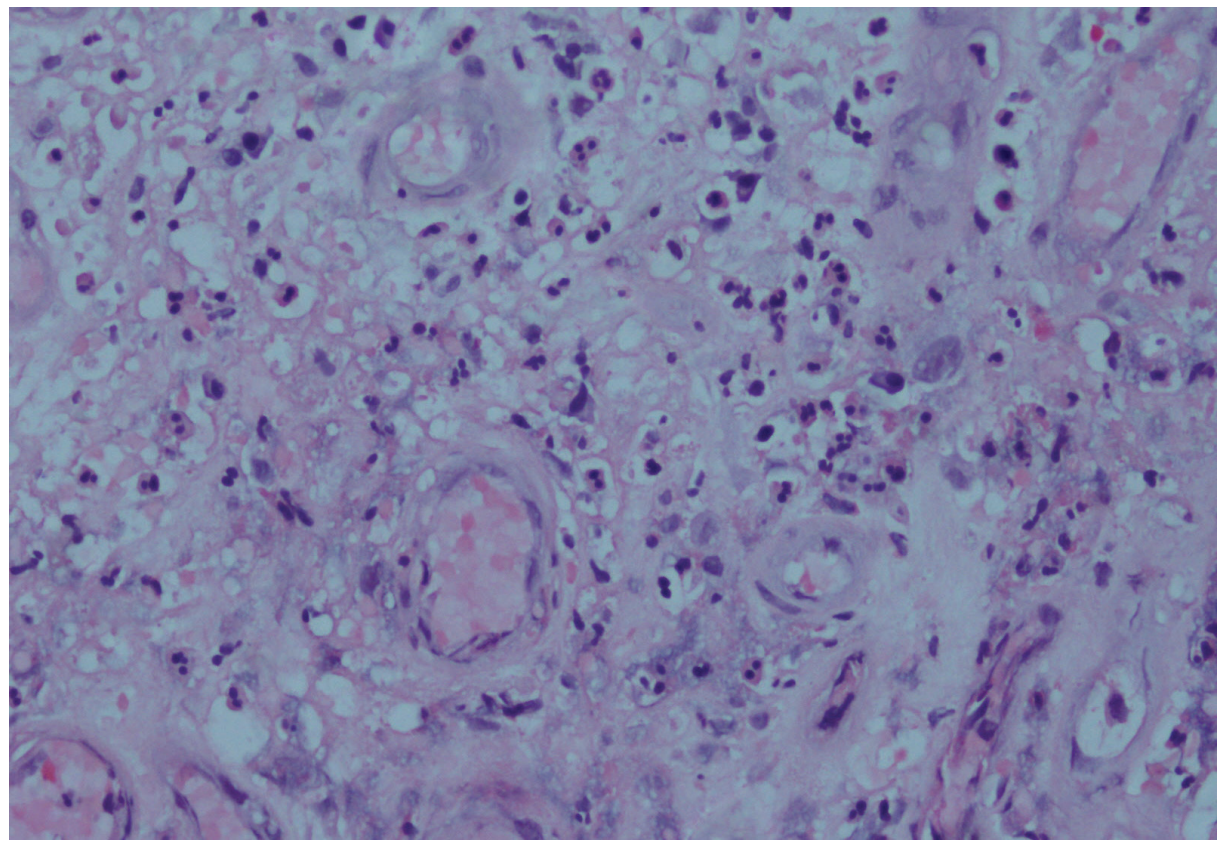

Fig. 1. Histopathological slide showing inflammed granulation tissue with no malignant cells.

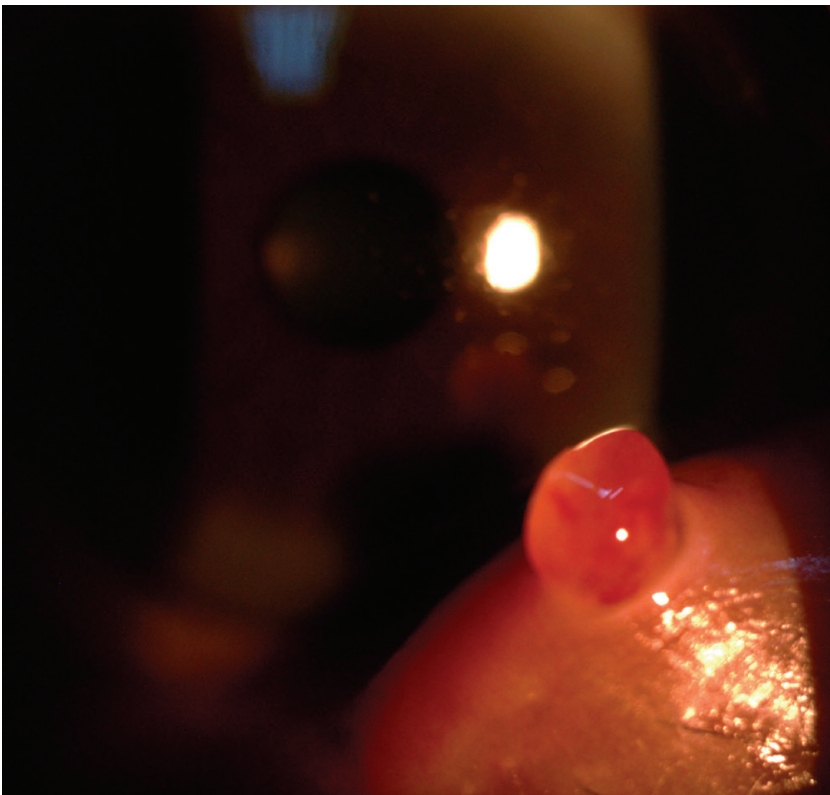

Fig. 2. Recurrence of the lower punctum granuloma. 
Clinically, there was no evidence of acute dacryocystitis or ocular surface disease. Hence, the recurrent granulation tissue was treated conservatively.

In summary, the uncommon granulation tissue formation should be informed to patients prior to performing syringing and probing. Topical steroids may be considered after the procedure.

\section{References}

1. Musadiq M., Mukherji S., Sandramouli S. Pyogenic granuloma following silicone punctal plugs: report of two cases. Orbit. 2005;24:149-151.

2. Ali MJ. Canalicular granuloma following recanalization by Sisler's trephine. Saudi J Ophthalmol. 2015;29(2):178-179.

3. Ahn HB, Seo JW, Roh MS et al. Canaliculitis with a papilloma-like mass caused by a temporary punctal plug. Ophthalmic Plast Reconstr Surg. 2009;25(5):413-414.

4. Han JH, Park JW, Kim SC. Reactive lymphoid hyperplasia of lacrimal canaliculus caused by a silicone plug. Ophthal Plast Reconstr Surg. 2012;28:e138-139.

5. Durmus M, Ozerturk Y, Bardak Y. Recurrent canalicular granuloma associated with silicone stent and its management. Marmara Medical Journal. 1999;12(1) 